\title{
Reef fish diversity in the Legon Bajak Port, Kemujan Island, Karimunjawa National Park
}

\author{
Siti Lathifah Maulany ${ }^{1}$, Ardyan Pramudya Kurniawan ${ }^{1 *}$ \\ ${ }^{1}$ Department of Biology, Faculty of Science and Technology, Universitas Islam Negeri Sunan Kalijaga \\ Jl. Marsda Adisucipto, D.I.Yogyakarta, Indonesia. 55281 \\ *Email: ardyan.kurniawan@uin-suka.ac.id
}

\begin{abstract}
Karimunjawa National Park provides substantial reef fish resources, leading to higher market demand for reef fish production. This study aims to determine the diversity of reef fish, particularly in regions where fishing boats dock, specifically in Legon Bajak Port, Kemujan Island, Karimunjawa National Park, Jepara, Central Java. The findings of this investigation should enrich previous studies. The study was conducted on the right and left sides of the Legon Bajak Port. The visual count of belt transects was used to obtain data on reef fish. The study results obtained the number of reef fish at the Legon Bajak Port was 2769 individuals $/ 500 \mathrm{~m}^{2}$ on the right and 1809 individuals $/ 500 \mathrm{~m}^{2}$ on the left side, representing 40 species, 26 genera, and 13 families. Istigobius rigilius had the largest density of individuals, with 233 individuals $/ 500 \mathrm{~m}^{2}$. The fish diversity index $\left(\mathrm{H}^{\prime}\right)$ value on the right side of the Legon Bajak Port was 3.24, which includes the high category, and on the left side was 2.89 , which includes the medium category. The dominance index (D) was between 0.05 and 0.06 (low), while the uniformity index (E) was between 0.74 and 0.83 (unstable in a stable community).
\end{abstract}

Keywords: coral fish potential; Central Java; diversity index; fish resources; habitat stability

Article History: Received 10 September 2021; Received in revised form 21 October 2021; Accepted 14 November 2021; Available online 30 December 2021

How to Cite This Article: Maulany SL, Kurniawan AP. 2021. Reef fish diversity in the Legon Bajak Port, Kemujan Island, Karimunjawa National Park. Biogenesis: Jurnal Ilmiah Biologi. vol 9(2): 189-197. doi: https://doi.org/10.24252/bio.v9i2.24091.

\section{INTRODUCTION}

Karimunjawa National Park is one of the national park conservation areas in Indonesia encompassing five distinct ecosystems and a diverse array of coral reefs (Kementerian Kelautan dan Perikanan, 2021). Coral reefs are ecosystems with a high level of diversity, owing to the variety of habitats on coral reefs (Messmer et al., 2011; Tyler et al., 2011). These habitat variables contribute to the diversity of fish found in coral reef ecosystems.

Sugianti \& Mujiyanto (2013) previously investigated the amount of reef fish diversity in Karimunjawa in several places including Pulau Kumbang, Pulau Burung, and Pulau Kecil. The study's findings indicated that the amount of reef fish diversity in the three locations was moderate, as shown by the species diversity index $\left(\mathrm{H}^{\prime}\right)$ value of 2463 . The study discovered 59 species of reef fish belonging to ten families. According to Yusuf (2013), coral reefs play a critical function in the reef fish community in Karimunjawa National Park. Coral reefs provide protection against waves for a habitat, a source of food, a breeding ground, and process catalyzes recovery by recruiting herbivores and larvae for marine life (Villanoy et al., 2012; Duarte et al., 2020). This condition triggers the number of reef fish to become abundant and population growth.

The enormous potential of reef fish on Karimunjawa Island increases market demand for reef fish production. This situation leads to various disturbances to reef fish populations. A disturbance occurs due to an extensive and irresponsible fishing attempt for marine commodities. Shellfishing, cyanide and arsenic poisoning, fish bombing, destructive fishing gear, are frequently detrimental to current fisheries and coral reefs in Indonesia reef fisheries (Setiawan, 2013; Putra et al., 2015; Yuliana et al., 2016). Additionally, activities that may degrade other marine resources include rock mining, underwater diving, anchor mooring, oil runoff from ships or boats, and conversion of mangrove forests to aquaculture ponds or settlement (Sambali et al., 2014; Johansen et al., 2017; Tynyakov et al., 2017; Yusuf et al., 2017; Forrester, 2020). As a result, aquatic resource sustainability is threatened, particularly reef fish. 
A number of issues arising from previous research exposes need the development of data and information on reef fish resources in the marine conservation area of Karimunjawa National Park. This study aims to determine the diversity of reef fish, particularly in regions where fishing boats dock, specifically in Legon Bajak Port, Kemujan Island, Karimunjawa National Park, Jepara, Central Java. With the requirement for reef fish biodiversity to be sustained, data on reef fish diversity and status become critical. The findings of this study are relevant and applicable as an addition to and complement to the policy of fisheries and conservation management strategies implemented in Karimunjawa National Park.

\section{MATERIALS AND METHODS}

Study area. The research was conducted in January-April 2021 at Legon Bajak Port on the right-left side of the beach located in Kemujan Village, Kemujan Island, Karimunjawa National Park. Geographically, the location of Legon Bajak Port on right side is located at $5^{\circ} 47^{\prime} 20.1^{\prime \prime S}, 110^{\circ} 28^{\prime} 32.6^{\prime \prime E}$ and Legon Bajak Port on left side at $5^{\circ} 47^{\prime} 12.5^{\prime \prime S}, 110^{\circ} 28^{\prime} 35.8^{\prime \prime E}$ (Fig. 1).

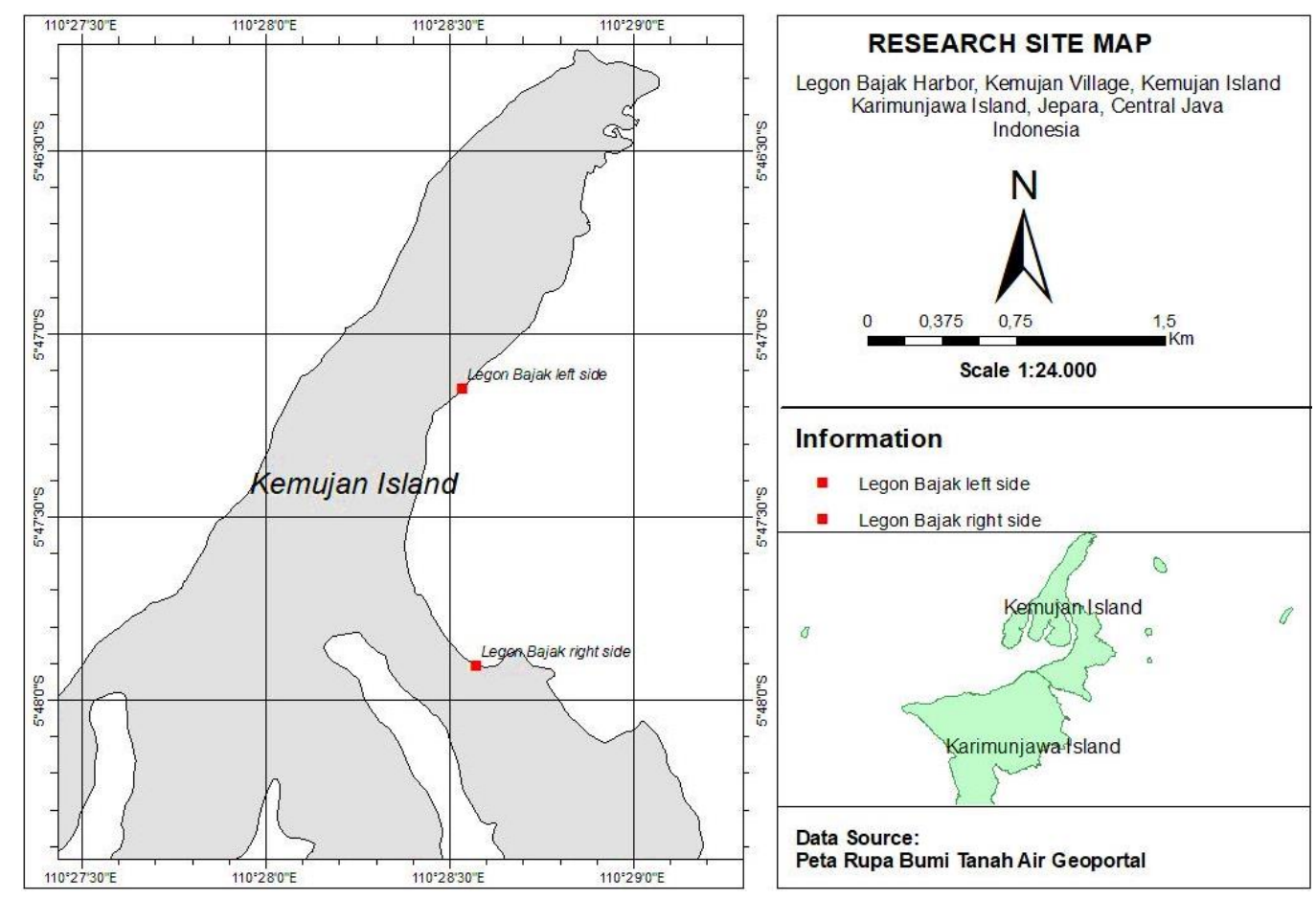

Fig. 1. Research location of Legon Bajak Port (right-left side).

Data collection tools and techniques. Reef fish data were collected using the visual census technique-belt transect concurring to English et al. (1997) at $250 \mathrm{~m}^{2}$ on each side (50 $\mathrm{m}$ length and $5 \mathrm{~m}$ width). The depth to be observed is 1-3 $\mathrm{m}$ above the transect line (Fig. 2 ). Groups of reef fish found, documented and recorded species and numbers. The reef fish groups were photographed with an underwater camera, and the species and numbers were recorded. Reef fish data were identified based on identification guidelines for coral fish species in Karimunjawa (Mulyadi, 2012) and field guidelines for identifying coral fish and marine invertebrates equipped with monitoring methods by Setiawan (2010). Environmental parameter data measured include temperature, $\mathrm{pH}, \mathrm{DO}$, and salinity.

Data analysis. Determination of reef fish species diversity was through ecological index analysis. Ecological indices include the Shannon diversity index $\left(\mathrm{H}^{\prime}\right)$, Simpson's dominance index (C), and the uniformity index (E). 


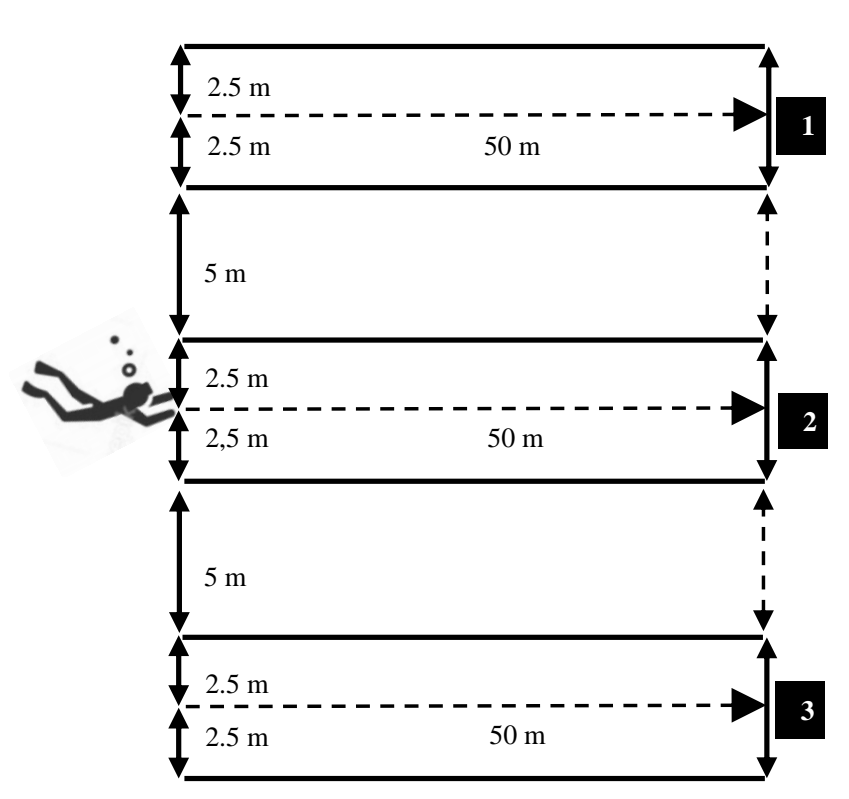

Fig. 2. Research sampling design with visual census technique-belt transect.

The diversity index is the balance of diversity by dividing the number of individuals of each species, the lowest value is obtained when all individuals come from a genus or only from one species, as formulated (Odum, 1953):

$H^{\prime}=-\sum \frac{\left(\frac{n i}{N}\right)}{\log \left(\frac{n i}{N}\right)}$

Notes:

$\mathrm{H}^{\prime}=$ diversity index

$\mathrm{Ni}=$ number of first individuals caught

$\mathrm{N}=$ total Number of individuals

The criteria for the diversity index (Krebs, 1989) are $\mathrm{H}^{\prime} 1=$ low diversity; $1<\mathrm{H}^{\prime} \leq 3=$ medium diversity; H' $3=$ high diversity. The uniformity index (E) shows a nearly uniform and evenly distributed abundance between species as follows (Odum, 1953):

$E=\frac{\mathrm{H}^{\prime}}{\ln S}$
Notes:

$\mathrm{E}=$ uniformity index

$\mathrm{H}^{\prime}=$ diversity index

$\mathrm{S}=$ number of types

The uniformity index value ranges from 0 1. The uniformity index value based on Krebs (1989) categorized are $0<$ E $0.5=$ community is depressed; $0.5<\mathrm{E} \quad 0.75=$ unstable community; $0.75<\mathrm{E} 1$ = stable community. The dominance index $(\mathrm{C})$ describes the dominance of an individual in an ecological community, as formulated (Krebs, 1989):

$H^{\prime}=\sum\left(\frac{n i}{N}\right)^{2}$

Notes:

$\mathrm{C}=$ dominance index

$\mathrm{Ni}=$ number of individuals of the $\mathrm{i}$-th species

$\mathrm{N}=$ number of individuals of all species

The dominance index value ranges from 0 - 1 with the following categories $0<\mathrm{C}<0.5=$ low dominance; $0.5<\mathrm{C} 0.75=$ moderate dominance; $0.75<\mathrm{C} 1.0=$ high dominance (Krebs, 1989).

\section{RESULTS AND DISCUSSION}

Composition and abundance of reef fish species. The location on the right and left sides of Legon Bajak Port showed 13 families, consisting of 40 species and 26 genera in 500 $\mathrm{m}^{2}$ observation area (Fig. 3). A total of 13 families were found on the right side of the Legon Bajak Port, including Apogonidae, Engraulidae, Gobiidae, Labridae, Lutjanidae, Monacanthidae, Nemipteridae, Pomacentridae, Pseudochromidae, Scaridae, Serranidae, Siganidae, and Syngnathidae, while at the Legon Bajak Port on the left side were found 11 families, including Apogonidae, Gobiidae, Labridae, Lutjanidae, Nemipteridae, Pomacentridae, Pseudochromidae, Scaridae, Serranidae, Siganidae, and Syngnathidae. 

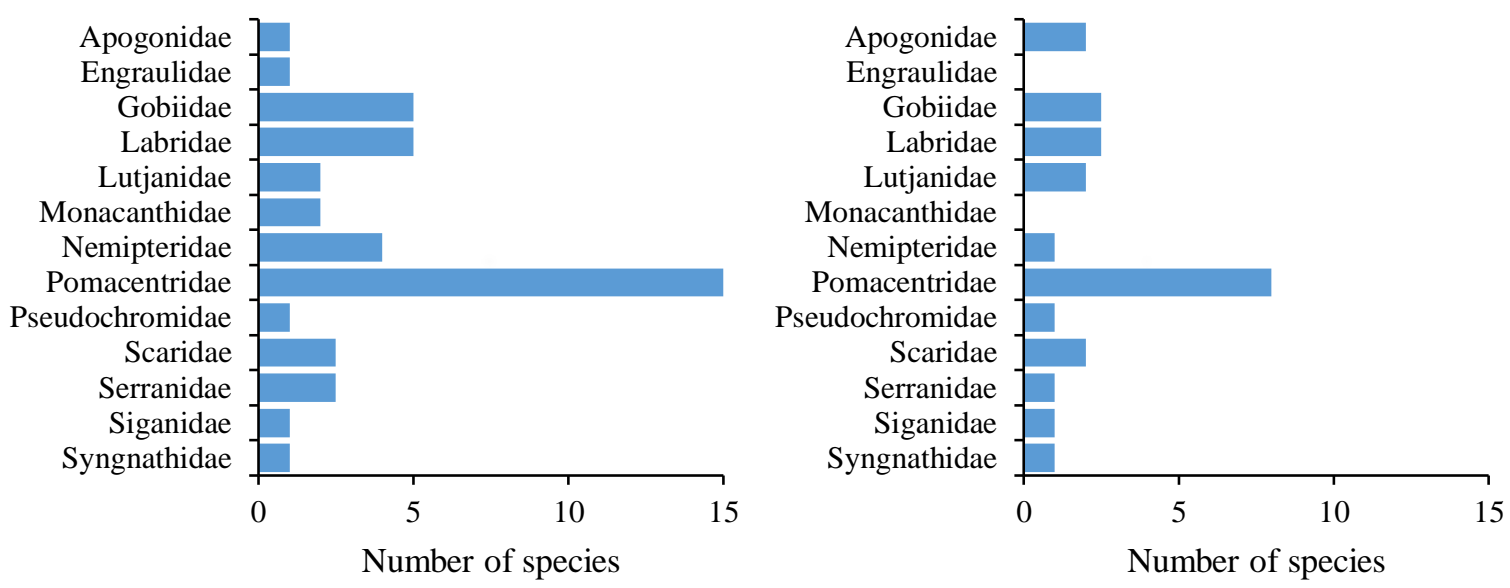

Fig. 3. Number of reef fish families found at the study site.

A total of 15 species of Pomacentridae are most frequently family found on the right side of Legon Bajak Port, while on the both of side of Legon Bajak Port, the three most frequently found families are the Pomacentridae, Labridae, and Gobiidae, which we will discuss (Fig. 3). These fish have a territorial attitude and will spend their lives on a coral reef. Additionally, the Gobiidae family is frequently found on coral reefs, as it feeds on large invertebrates that are abundant on coral reefs. Pomacentridae coral reefs are the most obvious due to their prominence as a fish family in coral reef ecosystems. It comprises several groups of Anemonefish, Humbugs, Pullers, and Damselfishes whose existence is largely reliant on the presence of coral reefs (Mulyadi, 2012). Certain species lay their eggs on the coral reefs guarded by male fish and incubate them on a rocky bottom for two to seven days. Pomacentridae comes in remarkable variety of colours, and each one is unique (Souza et al., 2011).

The Labridae family contains 70 genera and over 150 species in Asia, however only 56 species are found in Karimunjawa National Park (Parenti \& Randall, 2011; Balai Taman Nasional Karimunjawa, 2020). This fish is a valuable commodity that is much sought after by fishermen. It comes in a variety of shapes, sizes, colors, and behaviors depending on the species (Pambudi et al., 2019). The majority of Labridae are sand burrowers, invertebrate carnivores on coral reef bottoms and in the water column, some are plankton eaters, while others act as ectoparasites on larger fish (Wickel et al., 2016; Tatom-Naecker \& Westneat, 2018; Ulfah et al., 2020; McEachran $\&$ Fechhelm, 2021). The majority of the several species of wrasses are capable of changing their gender from male to female (hermaphrodite). Wrasses spawn in pairs at dusk in groups led by a brightly colored male and eggs are appearing on the surface of the water where the mother is not around to protect them. (Mulyadi, 2012; McEachran \& Fechhelm, 2021).

Gobiidae, commonly known as broomstick fish (gobies), inhabit shallow waters and and freshwater streams (Blom et al., 2016; Muthiadin et al., 2020). Although very few members of this family live on the bottom of the water, several of the more frequent species are found on coral reefs (Doll et al., 2021). Certain species hide in sand holes with shrimp and crab (Werding et al., 2016). This species of fish reproduces by laying eggs in holes, under rocks, or in abandoned clams, where males keep an eye on the eggs until they hatch, and the larvae swim freely in open water (Mulyadi, 2012; Teichert et al., 2013). Although Gobiidae is predicted to contain more than 2000 species as the largest marine fish family, only five have been detected in the Karimunjawa National Park, which are spread throughout the park's waterways (Froese \& Pauly, 2020; Balai Taman Nasional Karimunjawa, 2020). Fig. 4 illustrates the reef fish species and total number of individuals in our study. 
Legon Bajak Port on right side

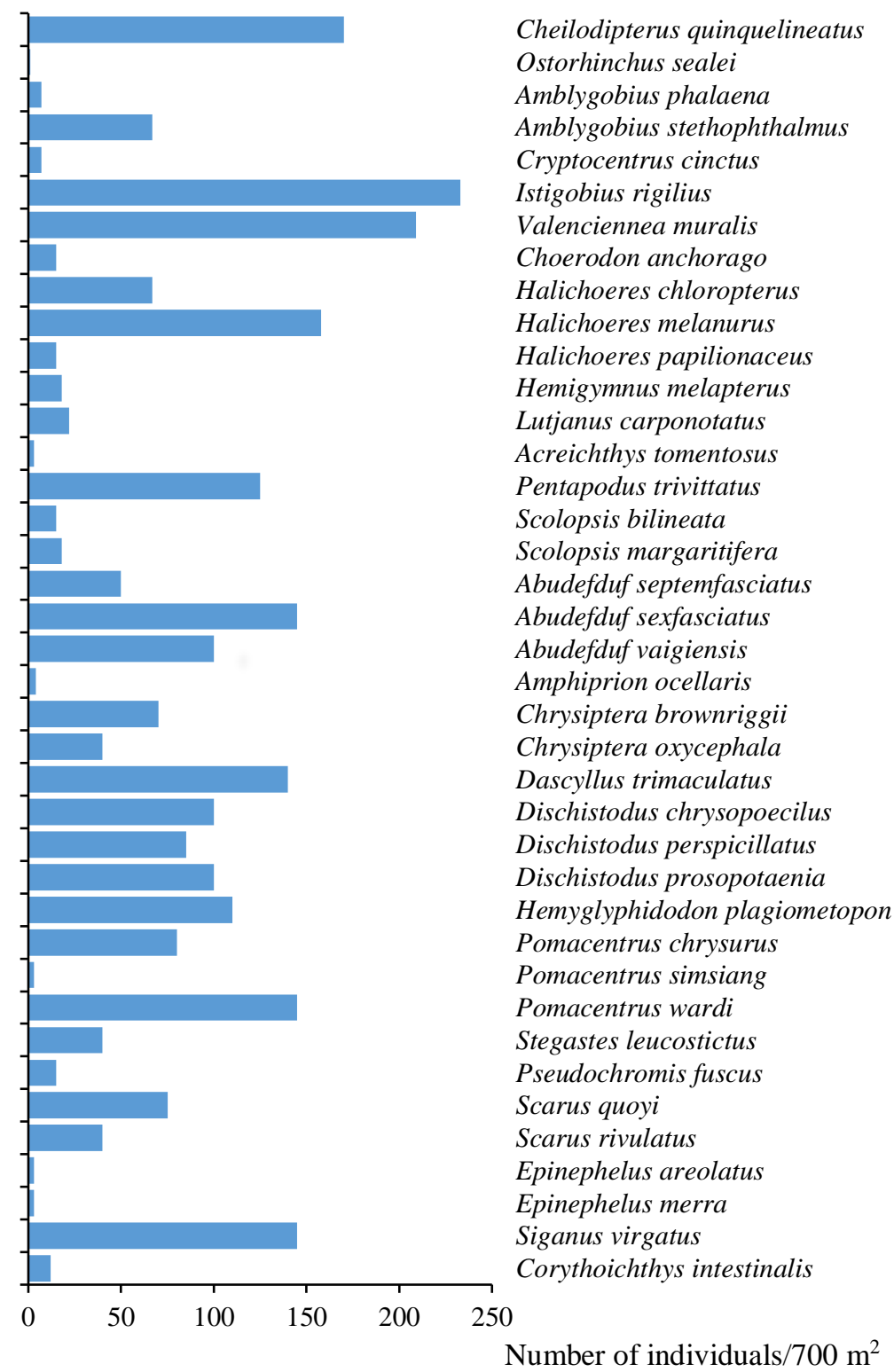

Legon Bajak Port on left side

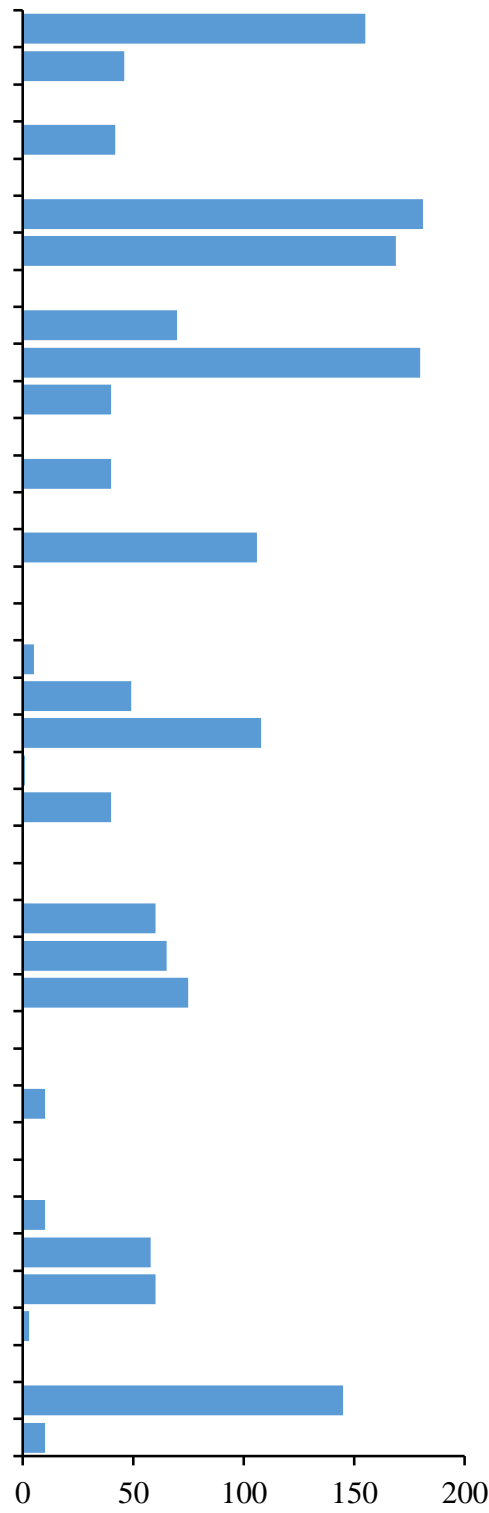

Fig. 4. Reef fish species found in Legon Bajak Port on the right-left sides.

The study identified 15 species belonging to the Pomacentridae family, including Abudefduf septemfasciatus, Abudefduf sexfasciatus, Abudefduf vaigiensis, Amphiprion ocellaris, Chrysiptera brownriggii, Chrysiptera oxycephala, Dascyllus trimaculatus, Dischistodus chrysopoecilus, Dischistodus perspicillatus, Dischistodus prosopotaenia, Hemyglyphidodon plagiometopon, Pomacentrus chrysurus, Pomacentrus simsiang, Pomacentrus wardi, and Stegastes leucostictus. A total of five reef fish species in Labridae family including Choerodon anchorago, Halichoeres chloropterus, Halichoeres melanurus,
Halichoeres papilionaceus, and Hemigymnus melapterus. While Amblygobius phalaena, Amblygobius stethophthalmus, Cryptocentrus cinctus, Istigobius rigilius, and Valenciennea muralis were discovered in the family Gobiidae.

The most significant number of individuals along the right side of the Legon Bajak Port were Istigobius rigilius as many as 233 individuals $/ 250 \mathrm{~m}^{2}$ and Valenciennea muralis as much as 209 individuals $/ 250 \mathrm{~m}^{2}$. The most numerous species on the left in the Legon Bajak Port is Istigobius rigilius, with 181 individuals $/ 250 \mathrm{~m}^{2}$ (Fig. 4). Both fish are included in the family Gobiidae. 
The location that impacts the existence of these fish is the sand substrate as a shelter for Gobiidae fish from predators. The Pomacentridae family has 1152 individuals per $250 \mathrm{~m}^{2}$ on the right side of the Legon Bajak Port, but only 409 individuals per $250 \mathrm{~m}^{2}$ on the left side. Pomacentridae is the most abundant family of fish found at Legon Bajak Port as coral reef habitats. Hence it is a resident species with territorial behavior that rarely travels more than a few miles from its food source and habitat.

Reef fish ecological index value. Fig. 5 illustrates the diversity, homogeneity, and dominance indexes of reef fish at the Legon Bajak Port on the right and left side.
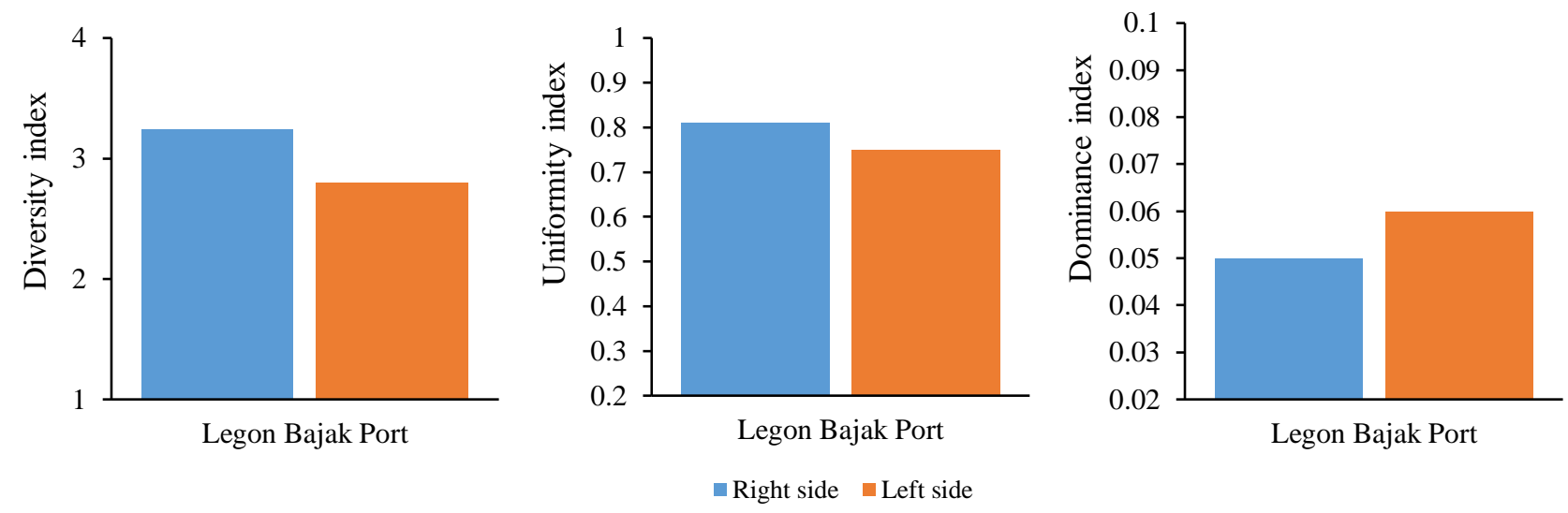

Fig. 5. The ecological index of reef fish at the study site.

The diversity index of reef fish obtained at the Legon Bajak Port on the right side is 3.24. (Fig. 5). In general, the value of the reef fish diversity index is in the high range. The waters on the location have a favorable environment. There is less pressure from the natural environment in which creatures live and human activity, resulting in a high variety index. A high diversity score denotes a secure and comfortable atmosphere and vice versa. The diversity index value at the Legon Bajak Port on the left is 2.89 , which is considered medium. Assuming the index value is $1<\mathrm{H}^{\prime} \leq 3$, the area has a moderate degree of diversity. Numerous factors could account for the difference in the diversity index score, including the low live coral cover at the observation site, as the majority of reef fish rely on coral reef substrates for shelter and food. The uniformity index quantifies whether or not the number of individual species is distributed uniformly. On the right side, the homogeneity index at the Legon Bajak Port is 0.84 , which is stable. This demonstrates that the species found at the observation site are more evenly distributed, as there are no dominant species. The dominance index value calculated for the right side of the Legon Bajak Port is 0.05 , indicating that the diversity index value is inversely proportional to the dominance index value in areas with a high diversity index value. It can be determined that the reef fish dominance at Legon Bajak Port is minimal. This suggests that a species does not dominate the amount of fish, and so is difficult to observe due to the even dispersion of fish.

Environmental quality conditions. Physical-chemical environmental parameters were measured during the study at the Legon Bajak Port on the right-left side including water surface temperature, water $\mathrm{pH}$, and salinity as shown in Fig. 6. 

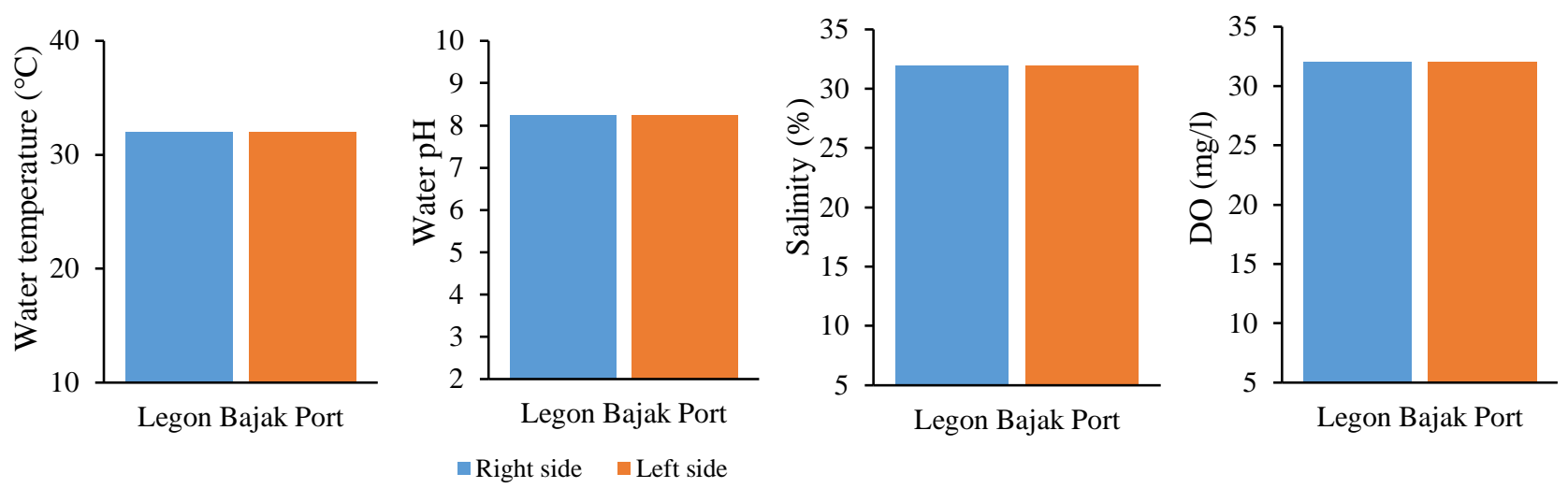

Fig. 6. The environmetal parameter of reef fish at the study site.

It is critical to understand the physical and chemical qualities of waterways since they will affect the lives of aquatic biota directly or indirectly. Temperature and salinity are two physical and chemical elements that might affect the growth of reef fish. The temperature value at each observation location is $32^{\circ} \mathrm{C}$, based on the measurement findings (Fig. 6). This number falls within the range typically required by reef-dwelling fish. A temperature range optimal for fish survival is between $25^{\circ} \mathrm{C}$ to $32^{\circ} \mathrm{C}$, generally found in tropical regions such as Indonesia. The Legon Bajak Port on the left side has a salinity range and $\mathrm{pH}$ of $31.7 \%$ and 8.3 , respectively. On the other hand, the right side is $32 \%$ and 8.26 . This salinity and $\mathrm{pH}$ value is still classified as normal. Generally, marine and coastal waters have a more stable $\mathrm{pH}$, typically ranging between 7.6 and 8.3, indicating alkaline. The majority of aquatic biotas prefer $\mathrm{pH}$ values between 7-8.5. In line with Franco \& dos Santos (2018), that the salinity, temperature, and $\mathrm{pH}$ of the water suggest the potential for reef fish to assemble, since they could be benefited by tropical conditions' warm waters and normal salinity. Surprisingly, Istigobius rigilius was the most abudant species at Ashmore Reef, Australia's North-west Shelf (Edgar et al., 2017). Additionally, Ashmore reefs are reported to have warm sea surface temperatures ranging from $25^{\circ} \mathrm{C}$ to $30.2^{\circ} \mathrm{C}$ (Wilson, 2014) and salinity values comparable to those in Legon Bajak Port, Karimunjawa National Park. Located only $120 \mathrm{~km}$ from Rote Island, East Nusa Tenggara, Ashmore Reef's proximity to the Indonesian archipelago contributes to the Ashmore reef's rich diversity of species, one of which being Istigobius rigilius. The dissolved oxygen measurement on the right side indicated an oxygen concentration of $8 \mathrm{mg} / \mathrm{l}$, while on the left indicated a concentration of $5 \mathrm{mg} / \mathrm{l}$. The observed dissolved oxygen value is factored into the study site's standard criteria for reef fish survival. Reef fish requires dissolved oxygen for various functions, including respiration, metabolic processes, and oxidation of organic and inorganic elements.

Marine biota, particularly reef fish, may sustain certain environmental factors in Legon Bajak Port. Regardless of the ecological index and environmental parameters in the waters surrounding Karimunjawa National Park, it would be preferable if activities that disrupt reef fish populations could be minimized through proper maintenance activities that can be accomplished through the synergy of government and local community.

\section{CONCLUSION}

The abundance of fish at the Legon Bajak Port is 2769 individuals $/ 500 \mathrm{~m}^{2}$ on the right and 1809 individuals $/ 500 \mathrm{~m}^{2}$ on the left, representing 40 species, 26 genera, and 13 families. On the right, the diversity index value $\left(\mathrm{H}^{\prime}\right)$ is 3.24 , which is in the high category, while on the left, it is 2.89 , which is in the medium category. The right side has a stable uniformity index of 0.84 , whereas the left side has a uniformity rating of 0.74 , which is unstable. The dominance index value is between 0.05 and 0.06 , which is considered modest. 


\section{ACKNOWLEDGEMENTS}

The authors would like to express their deepest gratitude to the Karimunjawa National Park Office for permitting research at the site. The authors thank the SPTN I staff, Mr. Kuswaidi and Mr. Yudi, who have provided suggestions and input, and the SPTN II staff, Mr. Kristiawan, Mr. Zainuddin, and Mr. Zainul as field supervisors, field teammate Dhanis Nuranggita Sari, who has helped with the data collection process.

\section{REFERENCES}

Balai Taman Nasional Karimunjawa. 2020. Statistik Balai Taman Nasional Karimunjawa tahun 2020. Semarang: Balai Taman Nasional Karimunjawa Indonesia. https://tnkarimunjawa.id/.

Blom EL, Mück I, Heubel K, Svensson O. 2016. Acoustic and visual courtship traits in two sympatric marine Gobiidae speciesPomatoschistus microps and Pomatoschistus minutus. Environmental Biology of Fishes. vol 99: 999-1007. doi: https://doi.org/10.1007/s10641016-0550-5.

Muthiadin C, Aziz IR, Hasyimuddin H, Nur F, Sijid SA, Azman S, Hadiaty RK, Alimuddin I. 2020. Penja fish (Genus: Sicyopterus) from Karama River, West Sulawesi, Indonesia: Growth pattern and habitat characteristics. Biodiversitas Journal of Biological Diversity. vol 21(10): 4959-4966. doi: https://doi.org/10.13057/biodiv/d211062.

Doll PC, Munday PL, Bonin MC, Jones GP. 2021. Habitat specialisation and overlap in coral reef gobies of the genus Eviota (Teleostei: Gobiidae). Marine Ecology Progress Series. vol 677: 81-94. doi: https://doi.org/10.3354/meps13863.

Duarte CM, Agusti S, Barbier E, Britten GL, Castilla JC, Gattuso JP, Fulweiler RW, Hughes TP, Knowlton N, Lovelock CE, Lotze HK. Predragovic M, Poloczanska E, Roberts C, Worm B. 12020. Rebuilding marine life. Nature. vol 580: 39-51. doi: https://doi.org/10.1038/s41586-020-2146-7.

Edgar G, Ceccarelli D, Stuart-Smith RD, Cooper AT. 2017. Reef Life survey assessment of coral reef biodiversity in the North-West Commonwealth Marine Reserves Network. Hobart: Reef Life Survey Foundation Incorporated. https://reeflifesurvey.com/.

English S, Wilkinson C, Baker V. 1997. Survey manual for tropical marine resource. $2^{\text {nd }}$ ed. Townsville: Australian Institute of Marine Science. p 408.

Forrester GE. 2020. The influence of boat moorings on anchoring and potential anchor damage to coral reefs. Ocean \& Coastal Management. vol 198: 1-7. doi: https://doi.org/10.1016/j.ocecoaman.2020.105354.

Franco AC, dos Santos LN. 2018. Habitat-dependent responses of tropical fish assemblages to environmental variables in a marine-estuarine transitional system. Estuarine, Coastal and Shelf Science. vol 211: 110-117. doi: https://doi.org/10.1016/j.ecss.2018.02.003.

Froese R, Pauly D. 2020. Family Gobiidae - Gobies. Makati: FishBase. https://www.fishbase.org/.

Johansen JL, Allan BJM, Rummer JL, Esbaugh AJ. 2017. Oil exposure disrupts early life-history stages of coral reef fishes via behavioural impairments. Nature Ecology \& Evolution. vol 1(8): 1146-1152. doi: https://doi.org/10.1038/s41559-017-0232-5.

Kementerian Kelautan dan Perikanan. 2021. Taman Nasional Laut Karimun Jawa. Jakarta: Direktorat Konservasi dan Keanekaragaman Hayati Laut, Direktorat Jenderal Pengelolaan Ruang Laut, Kementerian Kelautan dan Perikanan Republik Indonesia. http://kkji.kp3k.kkp.go.id/.

Krebs CJ. 1989. Ecological methodology. New York: Harper and Row Publishers Inc. p 765.

McEachran JD, Fechhelm JD. Labridae. In Fishes of the Gulf of Mexico, vol 2. Austin: University of Texas Press. pp 504-526. doi: https://doi.org/10.7560/706347-048.

Messmer V, Jones GP, Munday PL, Holbrook SJ, Schmitt RJ, Brooks AJ. 2011. Habitat biodiversity as a determinant of fish community structure on coral reefs. Ecology. vol 92(12): 2285-2298. doi: https://doi.org/10.1890/11-0037.1.

Mulyadi M, Sumaryati S, Rohman EA, Afendi N, Mardiko MSJE. 2012. Panduan identifikasi jenis ikan karang Di Karimunjawa. Semarang: Karimunjawa National Park. p 98.

Odum EP. 1953. Fundamentals of ecology. Philadelphia: W.B.Saunders Company. p 383. doi: https://doi.org/10.1002/sce.3730380426.

Pambudi DS, Nuryanto A, Prabowo RE. 2019. Phylogeny of marine ornamental fish members of Labridae from the South Coast of West Java, Indonesia. Biogenesis: Jurnal Ilmiah Biologi. vol 7(2): 139-147. doi: http://journal.uinalauddin.ac.id/index.php/biogenesis/article/view/1 0205.

Parenti P, Randall JE. 2011. Checklist of the species of the families Labridae and Scaridae: an update. Smithiana. vol 13: 29-43.

Putra AG, Ruswahyuni R, Widyorini N. 2015. Hubungan kelimpahan ikan dan tutupan karang lunak dengan kedalaman yang berbeda di Pulau Menjangan Kecil Taman Nasional Karimunjawa, Jawa Tengah. Management of Aquatic Resources Journal (MAQUARES). $\quad$ vol 4(2): 17-27. doi:https://doi.org/10.14710/marj.v4i2.8504.

Sambali H, Yulianda F, Bengen DG, Kamal MM. 2014. Analisis kelembagaan pengelola Taman Nasional Laut Kepulauan Seribu. Jurnal Sosial Ekonomi Kelautan dan Perikanan. vol 9(1): 105-113. doi: http://dx.doi.org/10.15578/jsekp.v9i1.1188.

Setiawan F. 2010. Panduan lapangan identifikasi ikan karang dan invertebrata laut. Manado: Wildlife Concervation Society. p 350. 
Setiawan H. 2013. Ancaman terhadap populasi kima (Tridacnidacna sp.) dan upaya konservasinya Di Taman Nasional Taka Bonerate. Buletin Eboni. vol 10(2): 137-147. doi: https://doi.org/10.20886/buleboni.5020.

Souza AT, Ilarri MI, Medeiros PR, Sampaio CLS, Floeter SR. 2011. Unusual colour patterns of territorial damselfish (Pomacentridae: Stegastes) in the southwestern Atlantic. Marine Biodiversity Records. vol 4: $\quad 1-5 . \quad$ doi: https://doi.org/10.1017/S1755267211001035.

Sugianti Y, Mujiyanto M. 2013. Biodiversitas ikan karang di perairan Taman Nasional Karimunjawa, Jepara. Bawal Widya Riset Perikanan Tangkap. vol 5(1): 23-31. doi: http://dx.doi.org/10.15578/bawal.5.1.2013.23-31.

Tatom-Naecker TM, Westneat MW. Burrowing fishes: kinematics, morphology and phylogeny of sanddiving wrasses (Labridae). Journal of Fish Biology. vol 93(5): 860-873. doi: https://doi.org/10.1111/jfb.13789.

Teichert N, Keith P, Valade P, Richarson M, Metzger M, Gaudin P. Breeding pattern and nest guarding in Sicyopterus lagocephalus, a widespread amphidromous Gobiidae. Journal of Ethology. vol 31(3): 239-247. doi: https://doi.org/10.1007/s10164-013-0372-2.

Tyler EHM, Manica A, Jiddawi N, Speight MR. 2011. A role for partially protected areas on coral reefs: maintaining fish diversity?. Aquatic Conservation: Marine and Freshwater Ecosystems. vol 21(3): 231-238. doi: https://doi.org/10.1002/aqc.1182.

Tynyakov J, Rousseau M, Chen M, Figus O, Belhassen Y, Shashar N. 2017. Artificial reefs as a means of spreading diving pressure in a coral reef environment. Ocean \& Coastal Management. vol 149: 159-164. doi: https://doi.org/10.1016/j.ocecoaman.2017.10.008.

Ulfah I, Yusuf S, Rappe RA, Bahar A, Haris A, Tresnati J, Tuwo A. 2020. Coral conditions and reef fish presence in the coral transplantation area on
Kapoposang Island, Pangkep Regency, South Sulawesi. IOP Conference Series: Earth and Environmental Science. vol 473: 1-11. doi: https://doi.org/10.1088/1755-1315/473/1/012058.

Villanoy C, David L, Cabrera O, Atrigenio M, Siringan F, Aliño P, Villaluz M. 2012. Coral reef ecosystems protect shore from high-energy waves under climate change scenarios. Climatic Change. vol 112(2): 493-505. doi: https://doi.org/10.1007/s10584-012-0399-3.

Werding B, Christensen B, Hiller A. 2016. Three way symbiosis between a goby, a shrimp, and a crab. Marine Biodiversity. vol 46(4): 897-900. doi: https://doi.org/10.1007/s12526-016-0453-x.

Wickel J, Pinault M, Fricke R. 2016. First record of a western Mascarene endemic, Halichoeres pelicieri (Actinopterygii: Perciformes: Labridae), from Reunion Island. Acta Ichthyologica et Piscatoria. vol 46(1): 33-35.

Wilson B. 2014. Kimberley marine biota. History and environment. Records of the Western Australian Museum Supplement. vol 84: 1-18. doi: https://doi.org/10.18195/issn.0313122x.84.2014.001-018.

Yuliana E, Fahrudin A, Boer M, Kamal MM, Pardede ST. 2016. The effectiveness of the zoning system in the management of reef fisheries in the marine protected area of Karimunjawa National Park, Indonesia. Aquaculture, Aquarium, Conservation \& Legislation. vol 9(3): 483-497.

Yusuf DN, Prasetyo LB, Kusmana C, Machfud M. 2017. Detection of mangrove disruption due to anthropogenic factor in protected area using GIS model: A case study in Konawe Selatan, Southeast Sulawesi. International Journal of Sciences: Basic and Applied Research (IJSBAR). vol 31: 31-42.

Yusuf M. 2013. Kondisi terumbu karang dan potensi ikan di perairan Taman Nasional Karimunjawa, Kabupaten Jepara. Buletin Oseanografi Marina. vol 2(2): 54-60. doi: https://doi.org/10.14710/buloma.v2i2.6940. 